Revista de Biología Marina y Oceanografía

Vol. 48, №3: 487-496, diciembre 2013

DOI 10.4067/S0718-19572013000300007

Article

\title{
Morphometric variability in sandy beach crustaceans of Isla Grande de Chiloé, Southern Chile
}

\author{
Variabilidad morfométrica en crustáceos de playas arenosas de la Isla Grande de Chiloé, sur de Chile
}

\author{
Heraldo Contreras ${ }^{1}$, Cristian Duarte ${ }^{2}$, Eduardo Jaramillo ${ }^{3}$ and Norka Fuentes ${ }^{4}$
}

${ }^{1}$ Centro Tecnológico para la Acuicultura Putemún, Instituto de Fomento Pesquero, Castro, Chile

${ }^{2}$ Departamento de Ecología y Biodiversidad, Facultad de Ecología y Recursos Naturales, Universidad Andres Bello, Santiago, Chile. heraldo.contreras@gmail.com

${ }^{3}$ Instituto de Ecología y Evolución, Universidad Austral de Chile, Valdivia, Chile

${ }^{4}$ Departamento de Acuicultura y Recursos Agroalimentarios, Universidad de los Lagos, Osorno, Chile

\begin{abstract}
Resumen.- La macroinfauna de playas arenosas expuestas en la costa chilena está dominada por crustáceos, los cuales muestran una zonación transversal; el anfípodo talítrido Orchestoidea tuberculata es el taxón dominante en los niveles superiores, el isópodo cirolánido Excirolana hirsuticauda lo es en la parte media del intermareal y el anomuro Emerita analoga es dominante en los niveles bajos. Este estudio examinó la variabilidad morfométrica de estas 3 especies de crustáceos en relación a los tipos morfodinámicos de playas. Las muestras fueron recolectadas durante la primavera de 2001 y se examinaron 7 caracteres morfológicos medidos en 30 adultos de cada especie: longitud del cuerpo, alto del cuerpo, ancho de cuerpo, longitud de las antenas y longitud de los urópodos. Los sitios de estudio se localizaron cerca de los $42^{\circ} \mathrm{S}$, un área donde los diferentes tipos de playa (i.e., reflectivo, intermedio y disipativo) se producen a lo largo de las costas septentrionales de los archipiélagos chilenos. La variabilidad morfométrica de 0 . tuberculata, E. hirsuticauda y E. analoga se analizó mediante análisis de cluster y de componentes principales. Los resultados de este estudio mostraron que, independientemente del tipo de playa, los individuos de 0 . tuberculata que habitan playas próximas presentan una mayor similitud que con aquellas que habitan playas lejanas. Los individuos de E. analoga que habitan en el mismo tipo de playa mostraron una mayor similitud que con aquellas que habitan en diferentes tipos de playas. Estos resultados se discuten en relación con la zonificación a través del intermareal y la historia natural de estas especies.
\end{abstract}

Palabras clave: Variabilidad morfométrica, macroinfauna, playas de arena

\begin{abstract}
The macroinfauna of exposed sandy beaches along the Chilean coast is dominated by crustaceans, which show an across-shore zonation; the talitrid amphipod Orchestoidea tuberculata as the dominant taxon in the upper levels, the cirolanid isopod Excirolana hirsuticauda is dominant in the mid-intertidal, and the anomuran crab Emerita analoga is common in the low levels. This study analyses samples collected during the spring of 2001 and 7 morphological characters were measured on 30 adults of each species: body length, body height, body width, antennae and uropodal exopod lengths. The study sites were located near $42^{\circ} \mathrm{S}$, an area where various beach types (i.e., reflective, intermediate and dissipative) occur along the northern coasts of the Chilean archipelagos. The morphometric variability of O. tuberculata, E. hirsuticauda and E. analoga was analyzed using cluster and principal component analysis. The results of this study showed that independently of beach type, individuals of 0 . tuberculata inhabiting proximal beaches showed greater similarity than individuals inhabiting beaches located distant from each other. Individuals of E. analoga inhabiting similar beach types showed greater similarity than individuals living in different beach types. These results are discussed in relation to acrossshore zonation and the natural history of these species.
\end{abstract}

Key words: Morphometric variability, macroinfauna, sandy beach

\section{INTRODUCTION}

Organisms occurring in sandy beaches show a high degree of plasticity in their behavior, ecophysiology, morphology, reproduction and characteristics of life history (Brown 1996, McLachlan et al. 1995). This has been associated with the high degree of environmental variability in these habitats, as they are among the most dynamic of marine environments (Soares et al. 1999). This dynamism is observed in the variations of physical characteristics among different types of beaches both in spatial and temporal scales, both short and long term (Soares et al. 1999). These littoral environments have been defined by the interactions of wave energy and grain size of the sand (e.g., Dean's parameter $(\Omega)$, sensu Short \& Wright 1983, McLachlan et al. 1995). 
Several studies have related diverse aspects of community structure (species richness, abundance, and biomass) with the macrofauna inhabiting the different morphodynamic types of sandy beach (e.g., McLachlan et al. 1993, McLachlan \& Jaramillo 1995, Jaramillo 2000). These studies have agreed that the community descriptors generally increase in magnitude from the reflective to the dissipative beachess (McArdle \& McLachlan 1992, McLachlan et al. 1993, 1995).

Recent studies have formulated additional predictions on a population level (e.g., Gómez \& Defeo 1999, Defeo et al. 2001, Contreras et al. 2003). Thus, the 'habitat harshness hypothesis' (Defeo et al. 2001) predicts an increase in community descriptors (e.g., diversity) and in a populations features (e.g., abundance, growth and fecundity) from reflective to dissipative conditions. These and other studies, however, have not recorded general patterns of different populations of the macroinfauna, and the variability observed in different aspects of the life histories of these organisms cannot be completely explained in terms of beach morphodynamics (Gómez \& Defeo 1999, Defeo et al. 2001, Defeo \& Martinez 2003 Contreras et al. 2003).

Studies carried out on sandy beaches along the Chilean coast describe 3 faunistic bands along the breadth of the intertidal (Castilla et al. 1977, Jaramillo 1987, Jaramillo et al. 1993, 1998), which coincide in general with the world scheme of zonation of macroinfauna of sandy beaches as proposed by Dahl (1952). The upper level of the intertidal zone of sandy beaches on the Chilean coast is numerically dominated by the talitrid amphipod Orchestoidea tuberculata Nicolet, 1849, the median level by the isopod Excirolana hirsuticauda Menzies, 1962 and the lower level by the anomuran crab Emerita analoga (Stimpson, 1857).

Orchestoidea tuberculata and E. hirsuticauda are species endemic to Chile, with ovoviviparous life cycles (Klapow 1970, Dexter 1977). E. analoga is one of the most abundant species in the wave swash zone of sandy beaches on the eastern shores of the Pacific Ocean, with a discontinuous distribution from Kodiak Island in Alaska to Baja California, and from northern Peru to southern Chile (Efford 1970, Núñez et al. 1974). The reproductive cycle of this species is indirect, with eggs carried on pleopods by the females for about 30 days (Boolotian et al. 1959), followed by a planktonic phase of three to four months (Johnson 1939, Efford 1970).
Body shape is a major component of the phenotype of an organism and can affect other traits, such as feeding and locomotion efficiency, susceptibility to predators and breeding success (Guill et al. 2003). These characteristics are partially determined by genes and strongly influenced by environmental conditions (Cabral et al. 2003). When environmental conditions exhibit a high variation, it is unlikely that a single phenotype confers a high reproductive success in all situations. In that case a change in phenotype of a species, affected by the environment (i.e., phenotypic plasticity), can provide a better environmental tolerance (Via et al. 1995). In this sense, the sandy beaches are highly changing environments and variable in their physical characteristics. Thus, the species that inhabit them have a high degree of phenotypic plasticity, such as behavior, ecophysiology, morphology and genetic structure (e.g., Scapini et al. 1988, McLachlan et al. 1995, Brown 1996, De Mattaeis et al. 2000, Dugan et al. 2000). This is due to high levels of phenotypic plasticity for physiological and morphological traits have been associated with highly changing environments (Hoffman \& Parsons 1991).

Few studies have analyzed the effect of the morphodynamics of sandy beaches on the phenotypic variability of morphometric traits of the organisms that inhabit them. In this context, McLachlan et al. (1995) found significant differences in shape and density of bivalves of beaches with different morphodynamics features. These authors found that bivalves from dissipative beaches often have a larger size, more rounded and less dense than those living reflective beaches. On the other hand, differences in growth and body size of different crustaceans have been related to variability in morphodynamic characteristics of sandy beaches. However, the morphodynamic state only affects the species that inhabit the low intertidal (Defeo \& Martinez 2003, Defeo et al. 2001, Gómez \& Defeo 1999, Contreras et al. 2003).

The northern coast of Chiloé Island ( $\left.c a ., 41^{\circ} \mathrm{S}\right)$ has the unique characteristic of presenting a broad variety of morphodynamic sandy beach types, with high macroinfaunal diversity (Jaramillo 2000). The present study evaluates the morphometric variability of the three above mentioned crustacean species, along a gradient of morphodynamic beach types found on the North coast of Chiloé Island, south-central Chile. Specifically, we hypothesized that beach morphodynamic characteristics will affect morphometric traits of those species inhabiting associated to the swash zone. 


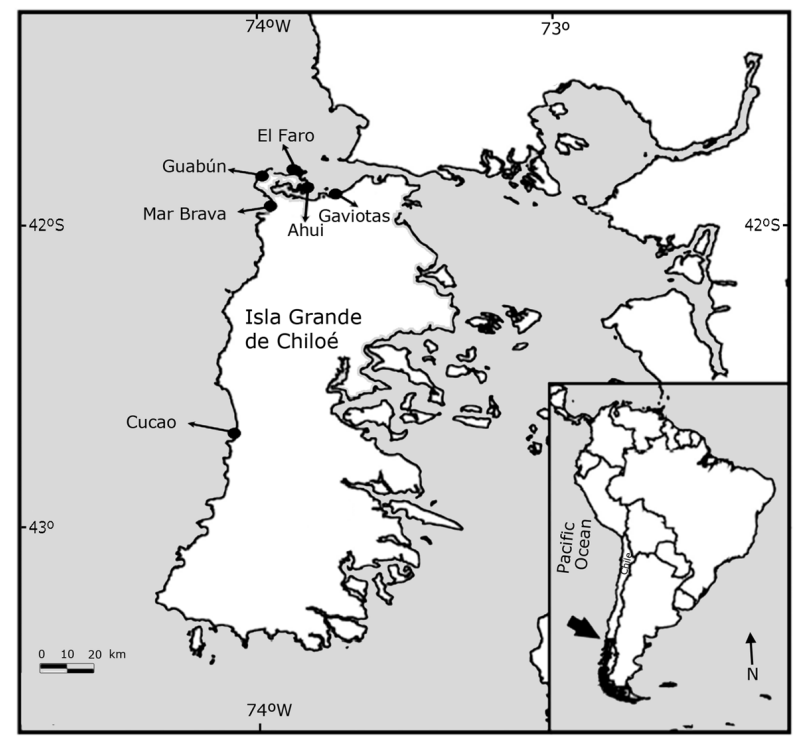

Figure 1. Location of beaches studied at the coast of Isla Grande de Chiloé / Ubicación de las playas estudiadas en las costas de la Isla Grande de Chiloé

\section{Materials ANd Methods}

Field sampling was carried out on 6 beaches in Chiloé Island in south-central Chile, including Mar Brava, Cucao, Guabún, Gaviotas and Ahui (ca., 40 S, Fig. 1). The morphodynamic characteristics of all the beaches were studied during July and November 2000 and February and June 2001. Wave height was estimated by measuring the height of breaking waves with graduated poles against the horizon, and adding the result to the height difference between the location of the observer and the lowest point where the backwash met the incoming swash bore. The wave period, measured with a stop watch, was the time interval between breaking waves. Sediment samples $(n=$ 3) for grain size analysis were collected from the highest tide level, effluent line and lowest swash level with a 3.5 $\mathrm{cm}$ diameter plastic cylinder driven to an approximate depth of $5 \mathrm{~cm}$. These analyses were carried out using a settling tube (Emery 1938). Mean grain size was calculated according to the moment computer method (SewardThompson \& Hails 1973) and used to estimate sand fall velocity according to the method described by Gibbs et al. (1971). Dean's parameter ( $\Omega$ sensu Short \& Wright 1983) was calculated from estimated mean wave height, wave period and sand fall velocity. Dean's parameter $(\Omega)$ has been used to characterize the morphodynamic state of microtidal sandy beaches, where $\Omega=$ wave height $(\mathrm{cm})$ / sand fall velocity $\left(\mathrm{cm} \mathrm{s}^{-1}\right) \mathrm{x}$ wave period (s). At least three morphodynamic types of beaches have been identified, including: i) reflective $(\Omega<2)$, with coarse sands of more than $600 \mu \mathrm{m}$ and steep slope, ii) intermediate ( $\Omega=$ between 2 and 5) with grain sizes from 200 to $600 \mu \mathrm{m}$ and steep or gentle slope, and iii) dissipative $(\Omega>5)$ with fine sands of less than $300 \mu \mathrm{m}$ and gentle slope.

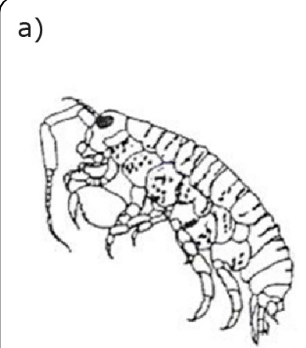

o. tuberculata

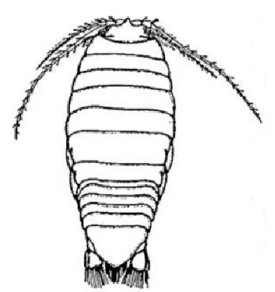

E. hirsuticauda

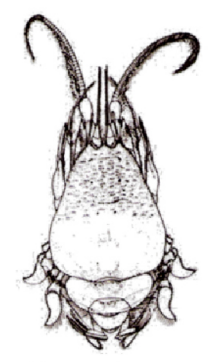

E. analoga b)

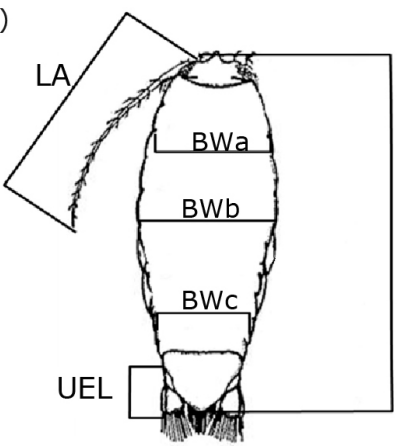

Figure 2. a) Species analyzed in this study; Orchestoidea tuberculata, Excirolana hirsuticauda y Emerita analoga (the organism are not in same scale), b) Measurements made in each specimens; body length (BL), body height (BH), 3 measures of body width (BW; $a, b, c)$, antennae length (LA) and uropodal exopod length (UEL) / a) Especies analizadas en este estudio; Orchestoidea tuberculata, Excirolana hirsuticauda y Emerita analoga (los organismos no están a la misma escala), b) Medidas realizadas en cada espécimen; longitud del cuerpo $(\mathrm{BL})$, alto del cuerpo $(\mathrm{BH}), 3$ medidas del ancho corporal (BW; a, b, c), longitud de la antena (LA) y longitud de los urópodos (UEL) 
One way analyses of variance were applied to test differences in annual means of slope, mean grain size, wave height, wave period and Dean's parameter $(\Omega)$ among beaches. These analyses were carried out using an annual mean (mean of the four seasonal samples). Cluster analyses and non-metric multidimensional scaling (MDS) were used to establish relationships among beaches. MDS was based upon a similarity matrix calculated with the Euclidean distance as run by the PRIMER (Plymouth Routines in Multivariate Ecological Research) program (Carr 1997).

Specimens of Orchestoidea tuberculata, Excirolana hirsuticauda and Emerita analoga (Fig. 2a) were collected during November and December 2001 at all beaches. Individuals of each species were collected directly from their distribution zones carefully by hand. Specimens of E. hirsuticauda were not found at the El Faro and Gaviotas beaches, and specimens of E. analoga were not found at the El Faro beach. Thirty adults were measured for each species for morphometric analysis. Individuals of each species were chosen keeping similar sized range (i.e., between 13 to $16 \mathrm{~mm}$ for $O$. tuberculata, 7 to $9 \mathrm{~mm}$ to $E$. hirsuticauda and 16 to $20 \mathrm{~mm}$ for E. analoga). Seven morphological characters were measured on each individual (Fig. 2b): body length (BL), body height $(\mathrm{BH})$, three measures of body width (BWa, b, c), length of antennae (LA) and uropodal exopod length (UEL) (Fig. 2b). Individuals of $O$. tuberculata and E. hirsuticauda were measured using a dissection lens equipped with a graticule whilst $E$. analoga specimens were measured with a digital caliper.

The measurements from each specimen were converted using natural logarithms and adjusted for size using Burnaby's method (Burnaby 1966, Rohlf \& Bookstein 1987). Principal Component Analyses were carried out on the adjusted data for each population of crustaceans. In these analyses the first principal component represents the shape, since the size variation is removed by the Burnaby adjustment (Weinberg \& Starczak 1989, Lessios $\&$ Weinberg 1994). Using the scores of the first principal component, Mahalanobis generalized distance was calculated between populations, and UPGMA cluster analyses were carried out (Lessios \& Weinberg 1994).

\section{Results}

During the sampling period the highest values for beach slope were found for Mar Brava and Cucao beaches (30 to 51, Table 1$)$, which were significantly higher $(P<0.001)$
Table 1. Seasonal variability of physical characteristic of the beaches studied / Variabilidad estacional de las características físicas de las playas estudiadas

\begin{tabular}{|c|c|c|c|c|}
\hline & 1 / slope & $\begin{array}{l}\text { wave height } \\
\text { (cm) }\end{array}$ & $\begin{array}{l}\text { period } \\
\text { (s) }\end{array}$ & $\Omega$ \\
\hline \multicolumn{5}{|l|}{ GAVIOTAS } \\
\hline winter & 9 & $64.8(14.8)$ & $9.9(2.0)$ & 0.6 \\
\hline spring & 8 & $44.7(12.9)$ & $8.7(1.9)$ & 0.4 \\
\hline summer & 10 & $32.1(10.6)$ & $11.5(2.8)$ & 0.2 \\
\hline autumn & 10 & $55.7(18.3)$ & $9.3(1.7)$ & 0.4 \\
\hline Annual mean (ds) & $9.1(1.3)$ & $49.3(14.1)$ & $9.9(1.2)$ & 0.4 \\
\hline \multicolumn{5}{|l|}{ GUABÚN } \\
\hline winter & 12 & $188.1(6.1)$ & $14.2(2.8)$ & 2.1 \\
\hline spring & 10 & $221.0(11.8)$ & $16.0(2.3)$ & 2.6 \\
\hline summer & 15 & $208.8(15.2)$ & $15.0(2.9)$ & 2.3 \\
\hline autumn & 10 & $70.8(20.4)$ & $14.2(2.5)$ & 2.0 \\
\hline Annual mean (ds) & 11.7 & $172.2(68.9)$ & $14.9(0.9)$ & 2.3 \\
\hline \multicolumn{5}{|l|}{ El FARO } \\
\hline winter & 14 & $230.1(9.7)$ & $12.9(2.4)$ & 1.2 \\
\hline spring & 13 & $198.7(6.7)$ & $13.9(2.5)$ & 2.3 \\
\hline summer & 19 & $189.5(48.6)$ & $15.2(2.3)$ & 1.0 \\
\hline autumn & 11 & $149.2(21.9)$ & $15.8(2.3)$ & 0.6 \\
\hline Annual mean (ds) & 14.2 & $191.8(33.3)$ & $14.4(1.3)$ & 1.3 \\
\hline \multicolumn{5}{|l|}{ AHUI } \\
\hline winter & 13 & $22.1(2.8)$ & $8.3(2.1)$ & 0.8 \\
\hline spring & 30 & $18.1(4.4)$ & $5.1(1.2)$ & 0.9 \\
\hline summer & 14 & $13.1(4.0)$ & $3.8(1.3)$ & 0.9 \\
\hline autumn & 15 & $27.3(5.2)$ & $3.7(1.2)$ & 1.0 \\
\hline Annual mean (ds) & 17.9 & $20.2(6.0)$ & $5.2(2.2)$ & 0.9 \\
\hline \multicolumn{5}{|l|}{ MAR BRAVA } \\
\hline winter & 40 & $363.3(4.8)$ & $18.5(2.2)$ & 8.3 \\
\hline spring & 51 & $253.5(6.1)$ & $23.2(3.5)$ & 6.4 \\
\hline summer & 50 & $317.9(6.8)$ & $18.2(2.7)$ & 7.4 \\
\hline autumn & 37 & $256.7(22.6)$ & $15.1(2.6)$ & 7.2 \\
\hline Annual mean (ds) & 44.8 & $297.9(52.7)$ & $18.7(3.3)$ & 7.3 \\
\hline \multicolumn{5}{|l|}{ CUCAO } \\
\hline winter & 30 & $496.0(2.1)$ & $18.5(2.2)$ & 9.9 \\
\hline spring & 33 & $320.6(14.0)$ & $15.7(2.2)$ & 8.6 \\
\hline summer & 31 & $674.7(12.6)$ & $20.7(2.2)$ & 8.7 \\
\hline autumn & 34 & $328.2(10.0)$ & $16.2(1.9)$ & 7.7 \\
\hline Annual mean (ds) & 32.1 & $454.9(167.4)$ & $17.8(2.3)$ & 8.7 \\
\hline
\end{tabular}

than those found in Ahui, El Faro, Guabún, and Gaviotas beaches.

Mar Brava, Ahui and Cucao had the finest sands with values between 180 and 280 ìm, while Guabún, EL Faro and Gaviotas had the coarsest sands, with values between 400 and 850 ìm (Table 1). Annual means of sand grain size at Mar Brava, Ahui and Cucao were significantly different from the other beaches studied $(P<0.001$, Fig. 3).

Annual mean values for wave height were lower at Ahui and Gaviotas (20.2 and $49.3 \mathrm{~cm}$, respectively), which were significantly higher than those observed in Mar Brava and Cucao (297 and $455 \mathrm{~cm}$, respectively) (Table 1, Fig. 3). Annual means of wave periods were shortest at 
Ahui and Gaviotas (5.2 and 9.9 s, respectively), while the other beaches had longer wave periods (means upper $14 \mathrm{~s}$ ) (Table 1, Fig. 3). Mar Brava and Cucao beaches were classified as dissipative, while Gaviotas and Ahui beaches were reflective based on the values of Dean's parameter $(\Omega)$. Guabún and El Faro were intermediate (Table 1, Fig. 3).

The cluster analysis (Fig. 4a), based on the granulometric and morphodynamic characteristics, basically grouped the beaches with similar morphodynamic characteristics (Mar Brava-Cucao, Guabún-El Faro, Ahui-Gaviotas). Similarities in physical characteristic between beaches sites resulting from MDS analyses are depicted in the plots shown in Figure $4 \mathrm{~b}$. The values of the stress statistics (stress $=0.00$ ) indicate that depictions of the relationship for each beach is good (Clarke 1993). The MDS plot reveals a gradient of physical characteristic from dissipative beaches (i.e., Mar BravaCucao) to reflectives (only Gaviotas beach).

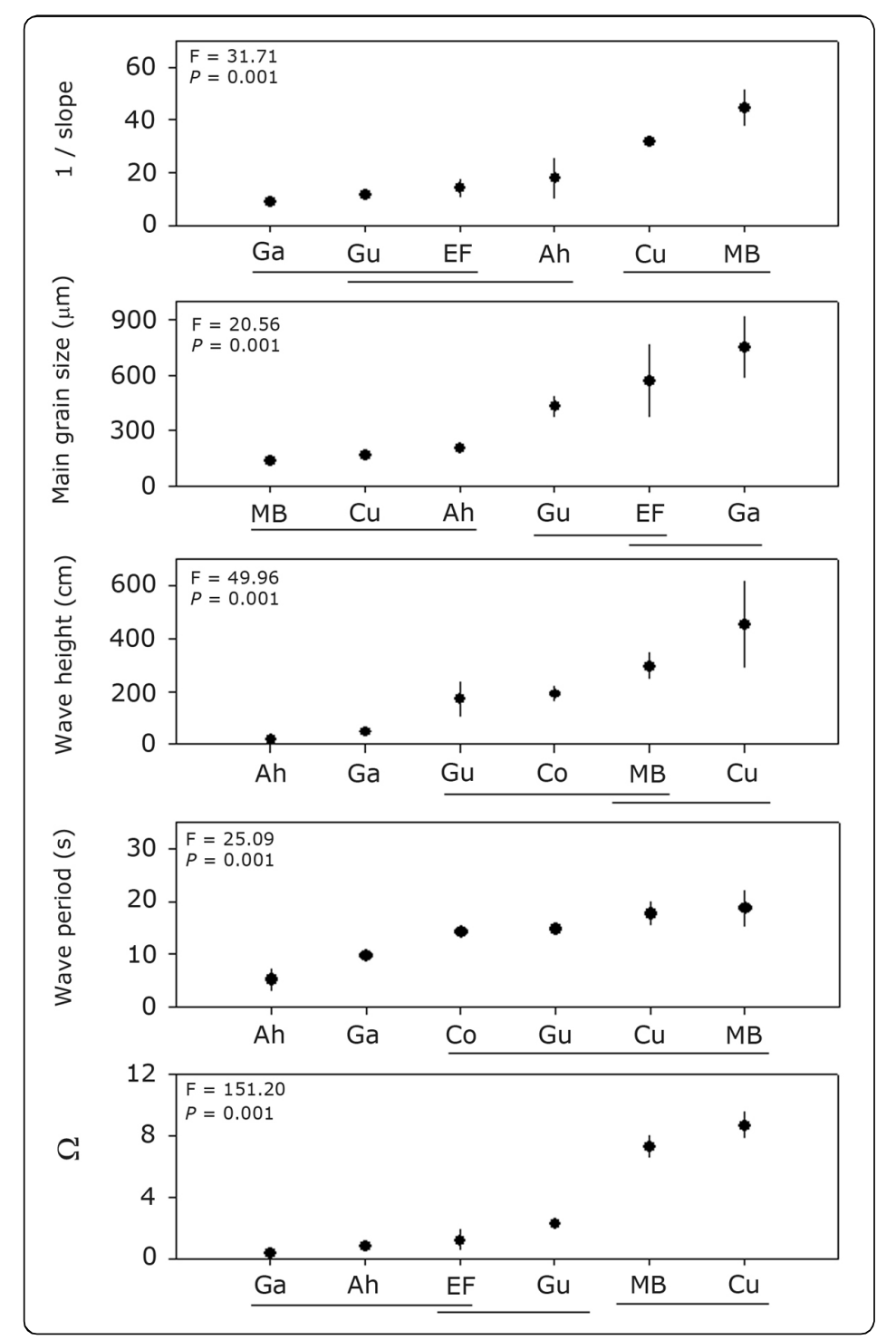

Figure 3. Geographical variability sediment and wave characteristics. Values of $F$ and $P$ are resulted from ANOVA. Lines link means not significantly different (results of Tukey's HSD a posteriori test). Ga= Gaviotas, Gu= Guabún, EF=El Faro, Ah= Ahui, MB= Mar Brava, Cu=Cucao / Variabilidad geográfica en las características de los sedimentos y olas. Valores de $\mathrm{F}$ y $\mathrm{P}$ son resultados de ANDEVA. Las líneas unen promedios que no difirieron significativamente entre sí (resultados del test a posteriori Tukey's HSD). Ga= Gaviotas, Gu= Guabún, EF= El Faro, Ah= Ahui, MB= Mar Brava, $\mathrm{Cu}=$ Cucao 


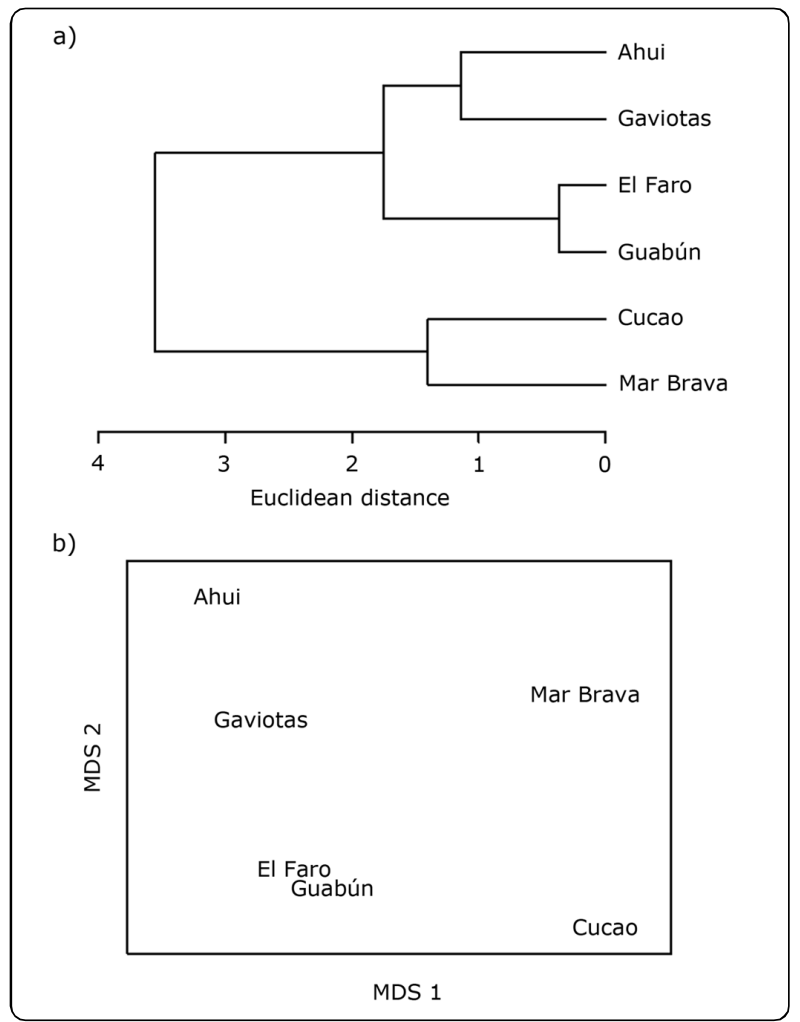

Figure 4. Results of Cluster analysis (a) and MDS (b) based on physical characteristics of the beaches studied / Resultados de los análisis de cluster (a) y EMD (b) basados en las características físicas de las playas estudiadas
The average values of the principal morphometric features are shown in Table 2. The first principal component (PC1) in all of the populations studied explained $80 \%$ of the variance based on the morphometric data analyzed. In $O$. tuberculata the Mahalanobis distances varied between 4.1 and 12.9 (Table 3), and showed a primary grouping of the populations from Ahui and Gaviotas beaches (Fig. 5); another group was composed of populations from El Faro, Mar Brava, and Guabún beaches. The Cucao beach populations were greatly distant from the other beaches. This analysis did not show relationships between morphometric similarity of organisms and morphodynamics of the beaches.

The Mahalanobis distance for Emerita hirsuticauda populations varied between 3.1 and 6.9 (Table 3). The cluster analysis showed high similarities in populations from Ahui, Mar Brava and Cucao beaches, but individuals from Guabún beach was the most dissimilar with the other beaches (Fig. 5).

The Mahalanobis distances for E. analoga populations varied between 2.9 and 8.2 (Table 2). The cluster analyses showed greater morphometric similarities between individuals from Mar Brava and Cucao beaches; whereas individuals from the Ahui and Gaviotas beaches showed more dissimilarity with those from other beaches (Fig. 5).

Table 2. Average values of the principal morphometric traits considered in this study. Body length (BL), body height (BH) and 3 measures of body width (BWa, $\mathbf{b}, \mathbf{C})$ / Valores promedios de los principales caracteres morfométricos considerados en este estudio. Longitud del cuerpo (BL), alto del cuerpo (BH) y 3 medidas del ancho corporal (BWa, b, c)

\begin{tabular}{|c|c|c|c|c|c|c|c|c|c|c|c|c|}
\hline & \multicolumn{2}{|c|}{ Gaviotas } & \multicolumn{2}{|c|}{ Guabún } & \multicolumn{2}{|c|}{ El Faro } & \multicolumn{2}{|c|}{ Ahui } & \multicolumn{2}{|c|}{ Mar Brava } & \multicolumn{2}{|c|}{ Cucao } \\
\hline \multicolumn{13}{|c|}{ Orchestoidea tuberculata } \\
\hline $\mathrm{BL}$ & 14.5 & (1.6) & 16.6 & (2.4) & 12.5 & (1.8) & 12.7 & (2.2) & 15.4 & (3.3) & 13.7 & (2.3) \\
\hline BWa & 2.9 & $(0.3)$ & 3.1 & $(0.5)$ & 2.6 & $(0.4)$ & 2.7 & $(0.4)$ & 3.1 & $(0.6)$ & 2.8 & $(0.3)$ \\
\hline BWb & 4.1 & $(0.6)$ & 4.8 & $(0.8)$ & 3.7 & $(0.6)$ & 3.8 & $(0.7)$ & 4.6 & (1.0) & 4.0 & $(0.5)$ \\
\hline BWc & 1.2 & $(0.1)$ & 1.3 & $(0.1)$ & 1.1 & $(0.2)$ & 1.1 & $(0.1)$ & 1.3 & $(0.2)$ & 1.2 & $(0.3)$ \\
\hline $\mathrm{BH}$ & 4.3 & $(0.5)$ & 4.9 & $(0.6)$ & 3.7 & $(0.5)$ & 3.8 & $(0.6)$ & 4.6 & $(0.8)$ & 4.2 & $(0.6)$ \\
\hline \multicolumn{13}{|c|}{ Excirolana hirsuticauda } \\
\hline BL & ---- & & 9.0 & $(1.0)$ & ---- & & 6.8 & (1.2) & 6.5 & (1.0) & 6.7 & (1.6) \\
\hline BWa & ---- & & 2.6 & $(0.2)$ & ---- & & 2.1 & $(0.4)$ & 1.7 & $(0.3)$ & 1.8 & $(0.4)$ \\
\hline $\mathrm{BWb}$ & ---- & & 4.3 & $(0.5)$ & ---- & & 3.1 & $(0.5)$ & 3.0 & $(0.4)$ & 3.0 & $(0.8)$ \\
\hline $\mathrm{BWc}$ & ---- & & 2.7 & $(0.3)$ & ---- & & 2.0 & $(0.3)$ & 1.7 & $(0.3)$ & 1.7 & $(0.4)$ \\
\hline $\mathrm{BH}$ & ---- & & 0.8 & $(0.1)$ & ---- & & 0.6 & $(0.1)$ & 0.6 & $(0.1)$ & 0.6 & $(0.1)$ \\
\hline \multicolumn{13}{|c|}{ Emerita analoga } \\
\hline $\mathrm{BL}$ & 14.5 & (3.2) & 14.6 & (3.2) & & & 12.5 & (2.3) & 21.7 & (4.4) & 15.3 & (3.8) \\
\hline BWa & 8.3 & $(1.7)$ & 8.2 & $(1.7)$ & & & 7.0 & (1.3) & 11.7 & (2.2) & 8.4 & (2.1) \\
\hline BWb & 12.2 & (2.8) & 12.4 & (3.2) & & & 10.5 & (2.2) & 18.1 & (3.7) & 13.0 & (3.4) \\
\hline BWc & 11.5 & (2.6) & 11.5 & (3.2) & & & 9.3 & (2.4) & 16.6 & (3.6) & 11.9 & (3.4) \\
\hline $\mathrm{BH}$ & 9.0 & (1.8) & 9.1 & (2.6) & & & 7.2 & (1.8) & 13.3 & (3.3) & 9.5 & (2.8) \\
\hline
\end{tabular}




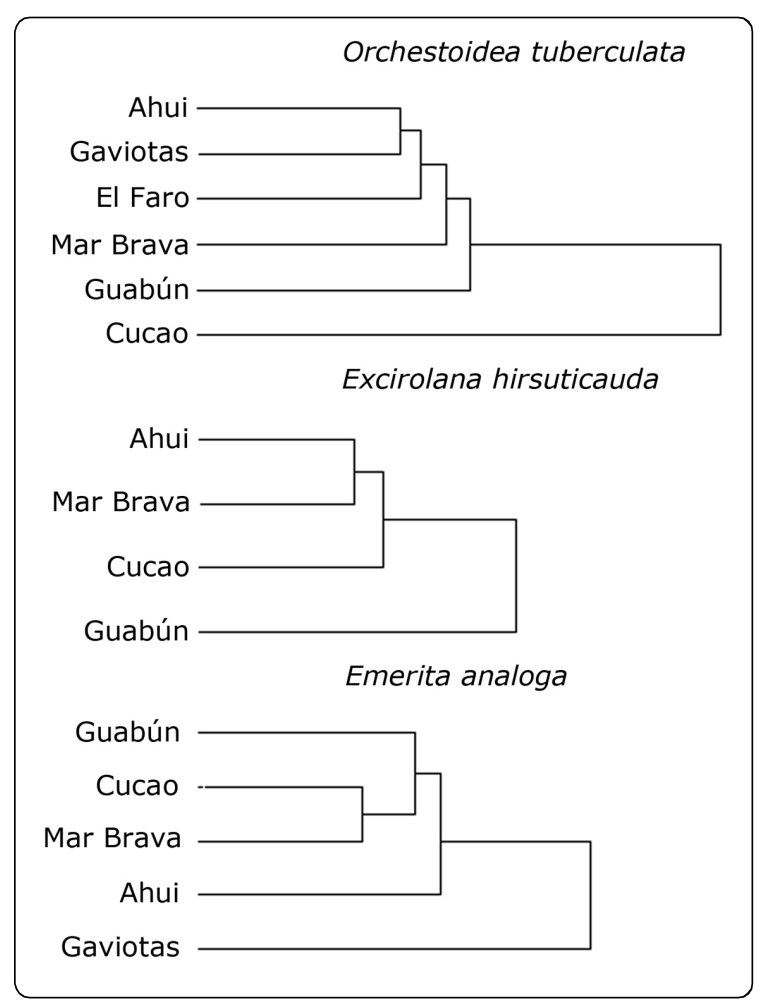

Figure 5. Results UPGMA clustering on the basis of Mahalanobis distances $D^{2}$ calculated from the first principal component (see materials and methods) / Resultados de análisis de cluster basados en las distancias de Mahalanobis $D^{2}$ calculadas a partir del primer componente principal (ver materiales y métodos)

\section{Discussion}

Environmental variability associated with the morphodynamics of sandy beaches has been mentioned as a cause of high plasticity of organisms that inhabit these environments (Brown 1996, Soares et al. 1999). Different studies have pointed out that the number of species and total abundance of the macrofauna tend to increase from reflective to dissipative beaches (Jaramillo \& McLachlan 1993, Jaramillo et al. 1993, McLachlan et al. 1993). However, no consistent patterns were detected for all components of the macrofauna at the population level; different results have been observed in different species. For instance, Contreras et al. (2000) and Defeo et al. (2001) found that population abundance, biomass and growth of crustaceans anomurans were significantly affected by the surf conditions. In contrast the results found by Contreras et al. (2003) and Gómez \& Defeo (1999) showed that those talitrids amphipods were not affected by the morphodynamic characteristics of the beaches.

Two aspects are fundamental for the attempt to evaluate phenotypic plasticity of the species studied; i)
Table 3. Matrix of Mahalonobis distances of the species studied I Matriz de las distancias de Mahalanobis de las especies estudiadas

\begin{tabular}{|c|c|c|c|c|c|}
\hline & Ahui & El Faro & Cucao & Guabún & $\begin{array}{c}\text { Mar } \\
\text { Brava }\end{array}$ \\
\hline \multicolumn{6}{|c|}{ Orchestoidea tuberculata } \\
\hline El Faro & 4.6 & & & & \\
\hline Cucao & 9.3 & 7.9 & & & \\
\hline Guabún & 6.3 & 6.0 & 12.9 & & \\
\hline Mar Brava & 5.7 & 5.1 & 11.1 & 5.2 & \\
\hline Gaviotas & 4.0 & 4.3 & 10.8 & 4.2 & 4.1 \\
\hline \multicolumn{6}{|c|}{ Emerita analoga } \\
\hline El Faro & ------ & & & & \\
\hline Cucao & 4.3 & ------- & & & \\
\hline Guabún & 4.6 & ------- & 3.9 & & \\
\hline Mar Brava & 4.1 & ------- & 2.9 & 3.7 & \\
\hline Gaviotas & 5.5 & ------- & 7.4 & 8.2 & 7.1 \\
\hline \multicolumn{6}{|c|}{ Excirolana hirsuticauda } \\
\hline El Faro & ------ & & & & \\
\hline Cucao & 3.9 & ------- & & & \\
\hline Guabún & 5.5 & ------- & 6.9 & & \\
\hline Mar Brava & 3.1 & ------- & 3.4 & 6.5 & \\
\hline Gaviotas & ------ & ------ & ------- & ------ & - \\
\hline
\end{tabular}

genetic differentiation in the populations studied and ii) environmental variability produced by the morphodynamism of the sandy beaches. In this regard, a study by Contreras (2006) showed low genetic differentiation between populations of $E$. analoga, which suggests a high genetic flow between these populations. In contrast $O$. tuberculata showed high levels of genetic differentiation and low genetic flow between populations. For this reason morphometric differences found in E. analoga would relate to the morphodynamics characteristics of the beaches, while those found in $O$. tuberculata could be related to genetic variability of these populations.

In the present study, the morphometric variability of the organisms with direct development (O. tuberculata and E. hirsuticauda) was greater than that encountered in the species with indirect development (E. analoga). The species which have a planktonic larval phase often show a greater dispersion rate, which promotes a greater genetic flow and higher genetic similarity between populations, as compared to species with direct development (Palumbi 1994, Grant \& Da Silva-Tatley 1997). On the other hand, species that inhabit distinct intertidal zones are differentially affected by the morphodynamic and physical variables that regulate these environments (Contreras et al. 2003). Thus, species that inhabit the lower intertidal zones are probably more affected by undercurrent conditions associated to distinct types of beaches than species that inhabit the upper intertidal zones (Dugan et al. 1991, 1994, Gómez \& Defeo 1999, 
Defeo et al. 2001, Contreras et al. 2003, Defeo \& Martínez 2003). Dispersion can be considered as an agent of exchanging individuals between geographically separated populations (De Matthaeis et al. 2000). Thus, the genetic structure of a population may be related to its distributional pattern and explained in relation to the limits given by the dispersal ability of individuals and habitat fragmentation. In this sense, the specific characteristics of the natural history of the 3 species and environmental variability of sandy beaches, may explain the differences found in this study.

Environmental variability is another factor to be considered in the analysis of morphometric variability among crustaceans of sandy beaches. The morphodynamic variability of sandy beaches has been suggested as a main factor in explaining community differences in the macroinfauna. Thus aspects such as richness, abundance, and biomass of the macroinfauna usually increase from the reflective to the dissipative extreme (Jaramillo \& McLachlan 1993, McLachlan \& Jaramillo 1995).

At the population level, the effects of morphodynamic variability of the sandy beaches on the macroinfauna are not clear, and depending on the patterns of zonation of the organisms they may be differently affected by morphodynamic characteristics of the beaches (Defeo et al. 2001, Defeo \& Martínez 2003, Contreras et al. 2003). In general, species inhabiting lower levels of the intertidal zone are more greatly affected by the backwash associated with the different morphodynamic types of sandy beaches in contrast to species occupying the upper levels of the intertidal zone which are less affected by these conditions (Gomez \& Defeo 1999, Contreras et al. 2003).

The results of the present study suggest that the morphometric variability of populations of the 3 species analyzed responds differently to the morphodynamic variability of the beaches studied. In E. analoga, the analyzes carried out support the hypothesis that the morphometric variability of this sand crab is affected by environmental conditions associated with the different types morphodynamic sandy beaches. Thus, reflective beaches populations were significantly different of the populations of dissipative and intermediate beaches. Also, intermediate and dissipative populations were different between both. In contrast, individuals of $O$. tuberculata and E. hirsuticauda did not show patterns of similarity associated with the morphodynamic differences in the beaches, and in general, individuals of geographically closer beaches were more similar to each other than groups of individuals from geographically separated beaches (e.g., populations of Cucao beach). Thus the morphodynamic variability of the sandy beaches cannot be considered the primary factor affecting the morphometric variability of these organisms.

McLachlan et al. (1995) found notable differences in the form and densities of bivalves in sandy beaches in relation to the different morphodynamic beach types. Thus species which occurred in dissipative beaches often were larger in size, more rounded, and less dense, than the same factors observed in the same species from reflective beaches. It may thus be concluded that the different morphological characteristics shown by these organisms are adaptations to different backwash conditions. Soares et al. (1998) observed differences in the density and the form of the the shells in populations of Donax serra related to the characteristics of the habitat in which these populations occurred.

Other studies have recorded the geographic variability in some reproductive aspects and life history of $E$. analoga (Dugan et al. 1991, Dugan et al. 1994, Dugan \& Hubbard 1996). Patterns similar to those observed in the cited studies have been recorded in comparative studies between populations of this species in northern and south-central Chile (Contreras et al. 1999, Contreras et al. 2000), suggesting that differences observed were due to different environmental conditions. Thus, some studies have related the variability observed in some population parameters and life history of these species to environmental aspects such as latitudinal gradient, food availability, and morphodynamic state of the beach (Dugan et al. 1994). The restricted spatial scale of the present study (ca., $100 \mathrm{~km}$ ) avoids anomalies due to latitudinal effects on other environmental aspects of the beaches studied.

In conclusion, this study found consistent morphometric differences among populations of crustaceans of sandy beaches occurring in a range of morphodynamic beach types on Chiloé Island. The sand crab, Emerita analoga, was the only component of the macrofauna analyzed which demonstrated morphometric similarities among individuals from corresponding beach types. In contrast, individuals of Orchestoidea tuberculata and Excirolana hirsuticauda demonstrated greater similarities among populations which occurred in beaches geographically closed independent from the morphodynamic characteristics of the beaches. In the future, it would be of interest extending the geographic range in this type of study, as well as evaluating the genetic differentiation among sandy beach crustacean populations in order to evaluate the 
validity of extending our present conclusions on a broader scale.

\section{ACKNOWLEDGMents}

Thank to Cesar Cuevas, Marcia Gonzalez and Sandra Silva for assistance in field and laboratory work. Also thank to Heriberto Figueroa for his help with the multivariate statistical analyses. Financial support for this study was provided by CONICYT-CHILE (Proyecto FONDECYT $n^{\circ}$ 2010018).

\section{LITERATURE CITED}

Beckwitt R. 1985. Population genetic of the sand crab Emerita analoga Stimpson, in southern California. Journal of Experimental Marine Biology and Ecology 91: 45-52.

Boehlert G \& R Kapenman. 1980. Variation of growth with latitude in two species of rockfish (Sebastes pinniger and S. diploproa) from the northeast Pacific Ocean. Marine Ecology Progress Series 3: 1-10.

Boolotian R, A Giese, A Farmanfarmalan \& J Tucker. 1959. Reproductive cycles of five west coast crabs. Physiological Zoology 32: 213-220.

Brown A. 1996. Behavioural plasticity as a key factor in the survival and evolution of the macrofauna on exposed sandy beaches. Revista Chilena de Historia Natural 69: 469-474.

Burnaby TP. 1966. Growth-invariant discriminant functions and generalized distances. Biometrics 22: 96-110.

Cabral HN, JF Márques, AL Rego, Al Catarino, J Figueiredo \& J García. 2003. Genetic and morphological variation of Synaptura lusitanica Capello, 1868, along the Portuguese coast. Journal of Sea Research 50: 167-175.

Carr MR. 1997. PRIMER user manual, 40 pp. Plymouth Marine Laboratory, Prospect Place.

Castilla JC, M Sanchez \& O Mena. 1977. Estudios ecológicos en la zona costera afectada por contaminación del 'Northern Breeze'. I. Introducción general y comunidades de playas de arena. Medio Ambiente 2: 53-64.

Contreras H. 2006. Variabilidad morfométrica y genética de crustáceos de playas arenosas expuestas de la costa de chile. Tesis Doctoral, Facultad de Ciencias, Universidad Austral de Chile, Valdivia, 114 pp.

Contreras H \& E Jaramillo. 2003. Geographical variation in natural history of the sandy beach isopod Excirolana hirsuticauda Menzies. Estuarine Coastal and Shelf Science 58S: $117-126$.

Contreras H, O Defeo \& E Jaramillo. 1999. Life history of Emerita analoga (Hippidae) in a sandy beach of south central Chile. Estuarine Coastal and Shelf Science 48: 101112.

Contreras H, E Jaramillo \& P Quijon. 2000. Natural history of Emerita analoga (Stimpson) (Anomura, Hippidae) in a sandy beach of northern Chile. Revista Chilena de Historia Natural 73: 705-715.

Contreras H, E Jaramillo, C Duarte \& A Mclachlan. 2003. Population abundances, growth and natural mortality of the crustacean macroinfauna at two sand beach morphodynamic types in southern Chile. Revista Chilena de Historia Natural 76: 543-561.

Dahl E. 1952. Some aspects of the ecology and zonation of the fauna on sandy beaches. Oikos 4: 1-27.

De Matthaeis E, M Cobolli, M Mattoccia \& F Scapini. 1995. Geographic variations in Talitrus saltator (Crustacea, Amphipoda): biochemical evidence. Bolletino di Zoologia 62:77-84.

De Matthaeis E, D Davolos, M Cobolli \& V Ketmaier. 2000. 1solation by distance in equilibrium and nonequilibrium populations of four Talitrid species in the Mediterranean sea. Evolution 54: 1606-1613.

Defeo O \& G Martínez. 2003. The habitat harshness hypothesis revisited: life history of the isopod Excirolana braziliensis in a sandy beaches with contrasting morphodynamics. Journal of the Marine Biological Association of the United Kingdom 83: 331-340.

Defeo O, J Gómez \& D Lercari. 2001. Testing the swash exclusion hypothesis in sandy beach populations: the mole crab Emerita braziliensis in Uruguay. Marine Ecology Progress Series 212: 159-170.

Dexter D. 1977. Natural history of the Pan-American sand beach isopod Excirolana braziliensis (Crustacea: Malacostraca). Journal of Zoology 183: 103-109.

Donn TE. 1990. Morphometrics of Donax serra Röding (Bivalvia: Donacidae) populations with contrasting zonation patterns. Journal of Coastal Research 6. 843-901.

Dugan JE \& DM Hubbard. 1996. Local variation in populations of sand crab, Emerita analoga on sandy beaches in southern California. Revista Chilena de Historia Natural 69: 579-588.

Dugan JE, DM Hubbard \& AM Wenner. 1991. Geographic variation in the reproductive biology of the sand crab, Emerita analoga (Stimpson) on the California coast. Journal of Experimental Marine Biology and Ecology 150: 63-81.

Dugan JE, AM Wenner \& DM Hubbard. 1994. Geographic variation in the life history of the sand crab, Emerita analoga (Stimpson) on the California coast: relationships to environmental variables. Journal of Experimental Marine Biology and Ecology 181: 225-278.

Dugan JE, DM Hubbard \& M Lastra. 2000. Burrowing abilities and swash behavior of three crabs, Emerita analoga Stimpson, Blepharipoda occidentalis Randall, and Lepidopa californica Efford (Anomura, Hippoidea), of exposed sandy beaches. Journal Experimental Marine Biology and Ecology 255: 229-245.

Efford IE. 1970. Distribution of the sand crab in the Genus Emerita (Decapoda:Hippidae). Crustaceana 18: 69-183. 
Emery KO. 1938. Rapid method of mechanical analysis of sands. Journal of Sedimentary Petrology 8: 105-111.

Gibbs RJ, MD Mathews \& DA Link. 1971. The relationship between sphere size and settling velocity. Journal of Sedimentary Petrology 41: 7-18.

Gómez J \& O Defeo. 1999. Life history of the sandhopper Pseudorchestoidea brasiliensis (Amphipoda) in sandy beaches with contrasting morphodynamics. Marine Ecology Progress Series 182: 209-220.

Grant WS \& FM Da Silva-Tatley. 1997. Lack genetically subdivided population structure in Bullia digitalis, a Southern African marine gastropods with lecitotrophic development. Marine Biology 129: 123-137.

Guill JM, CS Hood \& DC Heins. 2003. Body shape variation within and among three species of darters (Perciformes: Percidae). Ecology of Freshwater Fish 12: 134-140.

Hoffman AA \& PA Parsons. 1991. Evolutionary genetics and environmental stress, $284 \mathrm{pp}$. Oxford University Press, New York.

Janson K. 1982. Genetic and environmental effects on the growth rate of Littorina saxatilis Olivi. Marine Biology 69: 73-78.

Jaramillo E. 2000. The sand beach ecosystem of Chile. In: Seeliger U, L Drude de Lacerda \& B Kjerfve (eds). Coastal marine ecosystems of Latin America, pp. 219-226. SpringerVerlag, Berlin.

Jaramillo E \& A Mclachlan. 1993. Community and population responses of the macroinfauna to physical factors over a range of exposed sandy beaches in south-central Chile. Estuarine Coastal and Shelf Science 37: 615-624.

Jaramillo E, A Mclachlan \& P Coetzee. 1993. Intertidal zonation patterns of the macroinfauna over a range of exposed sandy beaches in south-central Chile. Marine Ecology Progress Series 101: 105-118.

Jaramillo E, F Carrasco, P Quijón, M Pino \& H Contreras. 1998. Distribución y estructura comunitaria de la macroinfauna betónica en la costa norte de Chile. Revista Chilena de Historia Natural 71: 459-478.

Johnson MW. 1939. The correlation of water movements and dispersal of pelagic larval stages of certain littoral animals, especially the sand crab, Emerita. Journal of Marine Research 11: 236-245.

Mclachlan A, E Jaramillo, TE Donn \& F Wessels. 1993. Sandy beach macrofauna communities and their control by the physical environment: a geographical comparison. Journal of Coastal Research 15: 27-38.
Mclachlan A, E Jaramillo, O Defeo, J Dugan, A De Ruyck \& P Coetzee. 1995. Adaptations of bivalves to different beach types. Journal of Experimental Marine Biology and Ecology 187: 147-160.

Nuñez, J, O Aracena \& MT Lopez. 1974. Emerita analoga en Llico, provincia de Curicó. (Crustacea, Decapoda, Hippidae). Boletín de la Sociedad de Biología de Concepción 48: 11-22.

Palumbi SR. 1994. Genetic divergence, reproductive isolation and marine speciation. Annual Review in Ecology and Systematics 25: 547-572.

Pigliucci M. 1996. How organism respond to environmental changes: from phenotypes to molecules (and vice versa). Trends in Ecology and Evolution 11: 168-173.

Rohlf FJ \& FL Bookstein. 1987. A comment on shearing as a method for 'size correction'. Systematic Zoology 36: 356367.

Scapini F, A Ercolini \& R Boccacci. 1988. Laboratory experiments on geotaxis, phototaxis, and anemotaxis in two species of littoral amphipods. Monitore Zoologico Italiano 22: 89-103.

Scheiner SM. 1993. Genetics and evolution of phenotypic plasticity. Annual Review of Ecology and Systematics 24: $35-68$

Seward-Thompson B \& J Hails. 1973. An appraisal on the computation of statistical parameters in grain size analysis. Sedimentology 11: 83-98.

Short AD \& LD Wright. 1983. Physical variability of sandy beaches. In: McLachlan A \& T Erasmus (eds). Sandy beaches as ecosystems, pp. 133-144. W Junk, The Hague.

Soares AG, RK Callahan \& A De Ruyck. 1998. Microevolution and phenotypic plasticity in Donax serra Röding (Bivalvia:Donacidae) on high energy sandy beach. Journal of Molluscan Studies 64: 407-421.

Soares AG, F Scapini, AC Brown \& A Mclachlan. 1999. Phenotypic plasticity, genetic similarity and evolutionary inertia in changing environments. Journal of Molluscan Studies 65: 136-139.

Via S, R Gomulkiewicz, G de Jong, SM Scheiner, CD Schlichting \& PH van Tienderen. 1995. Adaptive phenotypic plasticity: consensus and controversy. Trends in Ecology and Evolution 10: 212-217.

Weinberg JR \& VR Starczak. 1989. Morphological divergence of eastern Pacific and Caribean isopods: effects of a land barrier and the Panama Canal. Marine Biology 103: 143152.

Received 18 October 2012 and accepted 26 September 2013

Associate Editor: Gabriela Muñoz C. 